\title{
The Policies of Indonesian Government on Ethnic Chinese in the Context of Multiculturalism
}

\author{
Yeni Kurniawati Sumantri \\ Department of History Education \\ Faculty of Social Studies Education \\ Universitas Pendidikan Indonesia \\ Bandung, Indonesia \\ yenikurniawati@upi.edu
}

\author{
Iing Yulianti \\ Department of History Education \\ Faculty of Social Studies Education \\ Universitas Pendidikan Indonesia \\ Bandung, Indonesia \\ iingyulianti@upi.edu
}

\begin{abstract}
The sociocultural reality of Indonesia is a community which is ethnically, culturally and religiously plural. On one hand, the diversity is a blessing, but on the other hand, it also has a potential to generate conflict, especially if the differences are not well managed. Multiculturalism is a notion appreciating the diversity of cultures existing in a society. The existence of Chinese ethnic in Indonesia is a fact which ultimately leads to the need for openness to accept them as an integrated part of the community. This was shown by the inhabitants of our country before the existence of colonial powers that were able to build harmonious relationships with migrants from China. The policy of colonial power which imposed a system of separation between ethnic groups led to the absence of a harmonious relationship between these different groups of nations. The laws of wijkenstelsel and passenstelsel became a force that increasingly separated ethnic Chinese from other ethnic groups. For colonial rulers, this could be understood as a politics to strengthen their power in the midst of a separated society. The style of policy implemented by the Dutch colonial government was readopted by the New Order government, in addition to the existence of political policy. The purpose of the assimilation policy was the desire to remove the negative stereotype of ethnic Chinese that had been created since the colonial period and eliminated the exclusive nature of Chinese ethnic to achieve the unity within the community and to create a multicultural society.
\end{abstract}

Keywords-Government policy, Ethnic Chinese, Multiculturalism

\section{INTRODUCTION}

Indonesia is renowned for its pluralism society, in terms of ethnicity and culture as well as religion and belief. Pluralism also reaches to the level of economic prosperity, political views and territoriality, all of which actually have meaning and a strategic role for the people of Indonesia. However, simultaneously the pluralism of the community is also a dilemma in the framework of excavation, management, and development of the potential for the Indonesian nation to tread its future ladder.

In the context of national development, this multicultural term has formed an ideology called multiculturalism. The concept of multiculturalism cannot be equated with the concept of diversity in ethnicities or ethnic's cultures that characterize plural society since multiculturalism emphasizes cultural diversity in equality. The review of multiculturalism will inevitably analyze issues supporting this ideology, in cases of politics and democracy, justice and law enforcement, employment and business opportunity, human rights, community and minority cultural rights, ethical and moral principles, and level as well as quality of productivity.

Multiculturalism as previously elaborated has a great role in the development of the nation. Indonesia as a country standing on the diversity of culture requires the importance of multiculturalism in the establishment of the nation. With this multiculturalism, the principle of "Unity in Diversity" therefore, as set in the national principle, will be realized. The cultural diversity possessed by Indonesian will be an inspiration and potential for the nation's development so that the ideals to bring about a just, prosperous and prosperous Indonesia society as stated in the preamble of the 1945 Constitution can be achieved.

The current problematic is in fact, despite the existence of concept and embodiment of multiculturalism, and the possession of a common platform, Pancasila which aspires to unify Indonesia's diversity, the problems of ethnic conflicts, inter-religious strife, and the decline of respect for other people's culture still happen in Indonesia. Should the condition of a pluralistic society run agreeably and harmoniously, it will create social integration; otherwise, there will be social disintegration or social conflict. The influence of pluralistic society required to be considered due to its potential to lead to social conflict is the emergence of excessive primordialism and ethnic stereotypes. The plurality of Indonesian people can potentially help the nation to move forward and to develop together. Conversely, if the pluralism of the community is not well managed, it will nourish negative stereotypes between individuals and community groups that can eventually stretch the bonds of social solidarity.

The achievement and the acquisition of Indonesian's identity and personality are not processes that run by them, but they must be cultivated. The plural society of Indonesia comprising of various ethnic groups must strive to become a nation. From the Youth Pledge of 1928 to the post of the 
1945 Proclamation of Independence of Republic of Indonesia, coaching the national association and national unity is a priority in the struggle for independence and the nation's development of nation and character building [2]. One of the problems in the framework of association and unity of the Indonesia is the process of tribes' integration. One of examples is ethnic Chinese. Ethnic Chinese groups, who have existed in Indonesia for a long time as immigrants and demographics, are minority, apparently because some historical and psychological constraints still have not managed to blend and integrate fully into Indonesian society.

\section{RESUlT AND DisCUSSION}

\section{A. The Development Of Indonesian Government Policies On Ethnic Chinese In Multiculturalism Context}

The number of Chinese in Indonesia in the 1970s was approximately between 3 and 5 million [1]. It was difficult to determine the exact number. However, if the total number of Chinese in Indonesia in 1973 was 3 million people, then at a rate of 2.5 percent increase each year in 1983, it would reach a total of 3.75 million people. According to the Central Bureau of Statistics in 1973, among the 3 million Chinese, there had become 1,902,875 Indonesian citizens. In 1980, 4.2 million people constituted 2.8 percent of the total population of Indonesia. More than one million of whom were foreigners, in which 914,111 were the citizens of Republic China, 1,907 were Taiwanese, and 122,013 stateless were persons [1].

Despite this small number and belonging to minority group among Indonesians, the Chinese have considerable roles in the economic field. Then, the minority matter becomes a significantly serious issue. In addition, this problem becomes more complex due to that their integration process into the unity of the Indonesian nation faces various socio-culturally constraints.

The history shows that the migration of Chinese to Indonesia has been going on for a long time. "Die drangnachdem Suden" was indeed a tendency of the Chinese to move to the South in the past, and the region called Nan Yang was an area that continues to be the object of conquest in the days of the old dynasties. China's trade with the Malacca Strait using jung boats in the first date of AD had also proved that China had enough attention towards Southeast Asia since the early days. Dutch politics in the Jan Pieterzoon Coen period that included Chinese people to meet the need for rough laborers or porters in the fields of mining and plantation facilitated and enlarged the entry of Chinese migrants into Indonesia [2].

From the beginning, these Chinese migrants had showed a tendency to play a role in the economic field. Their position and their low and crude jobs as unskilled laborers were slowly and gradually abandoned and shifted surely into the commercial field. The conveniences gained from the Dutch political and economic system in Indonesia were exploited by the Chinese migrants to develop their role in the economic field. This is also supported by cultural values that prioritize craft, savviness, self-control, entrepreneurial spirit and skill, along with the social organization principles that are easily adapted and used. It caused them to succeed in economics in a country rich in nature whose inhabitants were totally different in orientation [3].

One of the ethnic Chinese descendants who lived in colonial times and who was economically successful was Tjong A Fie. Tjong A Fie is a plantation entrepreneur in Deli Serdang, North Sumatra, who was very rich in his time. One of the interesting things about the figure of Tjong A Fie is his attention to the natives. This can be seen in his testament in the form of the following testament.

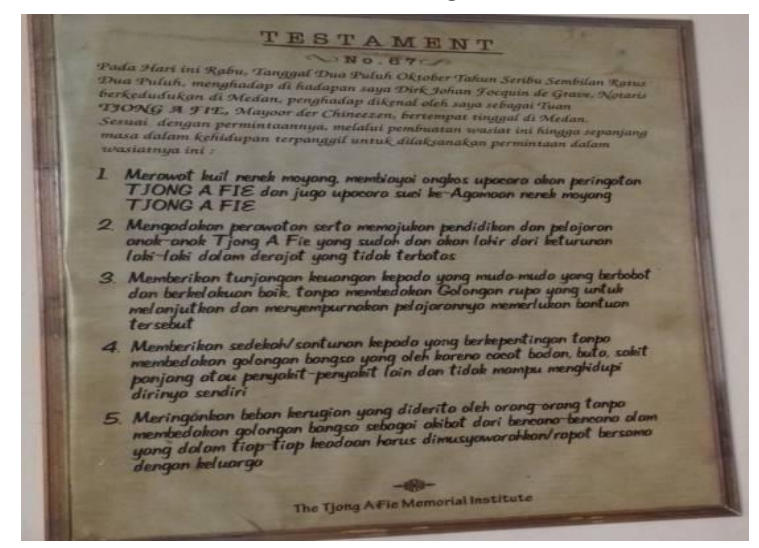

Fig 1 Testament of Tjong A Fie

This Tjong A Fie's testament shows that the multicultural attitude is in question. Without discrimination between nations and classes, Tjong A Fie provided educational assistance, compensation and burden of loss. This showed that there had been efforts of ethnic's Chinese descent to show multicultural attitude in the middle of exclusivity of Chinese people politically, socially and culturally

In the current reformation era, every citizen had equal rights in obtaining justice and in making life-changing decisions. The equality of rights should also be obtained by the Chinese as a part of Indonesian citizens. Such equality of rights could be seen from the freedom they get in the economic, political, educational, and socio-cultural. The efforts to equalize the rights of ethnic Chinese had been applied in the reign of B. J.Habibie. Revealed that President B. J. Habibie issued Presidential Instruction No. 26/1998 which abolished the use of indigenous and non-indigenous terms, and Presidential Decree No.4 / 1999 which abolished the Proof of Citizenship of the Republic of Indonesia (SBKRI). In order to fully implement democracy as a demand for reformation, President B. J. Habibie also provided a direction for the application of right equality in various fields; unfortunately all the rules were still being ignored for certain purposes [4].

The freedom gained by the ethnic of China at this time was started at the era of Abdurrahman Wahid, familiarly called Gus Dur, as he became the president of Indonesia. 
"Through Presidential Decree No. 6 of 2000, President Abdurrahman revoked the presidential decree that marginalized Chinese ethnicity in all fields" [5]. Gus Dur's strategic policy was then followed up by the next president, Megawati Soekarno Putri who issued Presidential Decree Number 19 of 2002 which inaugurated Imlek as a national holiday as well as the freedom gained by the Chinese in politics. Chinese people in Indonesia currently had equal opportunities to contribute in various areas of life, including in the economic, socio-cultural, and political fields in Indonesia. In the political field a Chinese was even able to become a head of the region.

The strategic policies pursued by B. J. Habibie, Gus Dur and Megawati Soekarno Putri were not without reason. If historically reviewed, ethnic Chinese life in Indonesia was not as easy as it is today. They were often subjected to discriminatory treatment. Their space in various areas of life was also limited. The life of Chinese people in Indonesia was very complex. They came as strangers who then mingled with the natives, some of whom eventually had a sense of nationalism towards Indonesia. However, their existence was frequently still regarded as a problem that must be resolved immediately. These problems arouse not only because of their existence as a minority group who have employment as merchants, but also because of the relation to their actual identity. Viewed from the terms of culture, the Chinese in Indonesia is divided into two, crossbreed Chinese and full-blooded or native Chinese [6] explained that:

Crossbreeds are the Chinese who have long lived in Indonesia and generally have "mingled" with the native of Indonesia: They use Indonesian language and behave like an indigenous. Full-blooded is a "newcomer", generally only one to two generations and still speak Chinese (pp. 252).

Viewed from previous periods, especially in the field of politics, the Chinese have three orientations, the Dutch government - oriented, some are China-oriented, and some were Indonesia-oriented. The crossbreeds were those who usually had a political orientation towards Indonesia as they had already mixed with the natives. [7] has explained that:

In the colonial era in Indonesia, there were three major socio-political orientations among the local Chinese, they are those who were Chinese oriented; those oriented to the Dutch East Indies - who understood their position as Dutch subjects while continuing as crossbreed Chinese; and those who call themselves as the next members of Indonesian. (p. 70).

It showed the differences of the ethnic Chinese groups themselves, but they were often regarded as homogeneous minorities who liked to be in groups. The existence of such image raised a negative assumption for the indigenous. "The Chinese are in groups, they distance themselves from social interaction and prefer to live in separate areas" [8]. Moreover, the existence of these three political orientations was one of the reasons why indigenous peoples had a fickle view of the Chinese, and such fluctuated view tends to be negative. Finally, the relations between the two sides, the natives and the Chinese, were tenuous which caused indigenous mistrust of the Chinese.

The tenuous relationship between the indigenous and the Chinese was initially triggered by Dutch propaganda. The Dutch government saw the harmony existing between the indigenous and the Chinese people as a threat that could hinder their intention to dominate Indonesia. The Dutch government hence did political separation to the indigenous and the Chinese people in terms of applied policy. The political strategy of the separation by the Dutch was apparently successful and further encouraged the indigenous disbelief towards the Chinese. Given this perception, it has engendered an impact on the Chinese's positions and existences in various areas of life.

Entering the independence era, the existence of the Chinese people was still in the spotlight and was an awry period for their position in Indonesia, especially about the uncertainty of their citizenship status which ultimately led to the law draft restricting the number of Chinese people who could become Indonesian citizens in 1954. The emergence of this law triggered the political consciousness of the Chinese which then led them to participate in politics through formal and non-formal channels. Through formal path, they established organizations in which the organizations founded at that time were more inclined towards the problem of ethnic Chinese integration in Indonesia. Around 1954, they began to establish an organization called the Indonesian Citizenship Consultative Board (Baperki) to channel their aspirations. Baperki focused on the idea ssof integration as an Indonesian citizen and opposed all forms of racial discrimination. As stated by Suryadinata [9] that "Baperki's main purpose is to assist and to contribute to the society and government's efforts to realize the content and the spirit of a democratic constitutional country and the concept of citizenship."

Time passed and Baperki focused on the Chinese ethnic's citizenship issues which still became a problem Indonesia. Baperki emphasized the idea of integration to solve the problem. "This integration idea simply states that Chinese people should be accepted as a tribal group like other tribes in the Indonesian territory" [10]. Fundamentally, this integration concept drove at solving the Chinese problem in Indonesia by doing amalgamation into the indigenous people and still bringing the cultures as a Chinese. This was reinforced [8] which revealed that every claim which demanded them to abandon their cultural traits was considered to be a discriminatory and it was unacceptable.

In its development, Baperki was confronted to 'left' and 'right' forces. After the implementation of Guided Democracy and Indonesian politics began to lead to the left, Baperki began to abandon his earlier stance. Its chairman, 
Siauw Giok Tjhan, particularly argued that racial problems would vanish in case of the achievement of Indonesian socialism [8]. Eventually, Baperki increasingly complied with President Soekarno who was aggressively implementing Manipol Usdek and Nasakom. This triggered Baperki to bring out a stigma among the public and the opposition that they were one of the left forces beside the PKI. It was also one of the most decisive foundations of their political position in the next regime. This was further strengthened when the government issued a regulation that distinguished the status of traders in the economic field. Then, the Indonesian government - led by Soekarno - issued Presidential Decree no.10 which essentially distinguished indigenous traders and foreign traders. Upon the issuance of the regulation, the Chinese felt that the idea of integration was not enough to solve the problems of Chinese ethnicity in Indonesia, evidenced by the still-existing distinction between the foreign and the native.

The answer of the integration ideal failure brought out by Baperki in 1961 led to the emergence of Chinese political figures that supported the idea of assimilation as the most appropriate way to interfere with indigenous peoples. In order to realize the assimilation, an organization called Institute for the Development of National (LPKB) was established, whose main objective was to emulate the previous organization -Baperki - which tended to support the 'integratively' assimilation. This was in line with what expressed [7] that:

In their view, to be "pure and patriotic Indonesians", the Chinese must be merged into indigenous Indonesians so that the Chinese minority is no longer a separate group (pp. 67).

Entering the New Order regime, the Chinese problem was still unfinished. The existence of a negative stigma for ethnic Chinese was still a complicated issue. The existence of Chinese in Indonesia stayed seen as a problem that had to be resolved. Therefore, the government of the New Order period supported and implemented a policy of total assimilation ever conducted by the organization of LPKB against the Chinese people in Indonesia. "The aim of this policy is to reduce the ethnic characteristics of Chinese, so that they can be assimilated with 'indigenous population' [6]. In this case, Indonesian government required the Chinese to absorb indigenous cultures. The total assimilation policy covered all aspects of Chinese life in Indonesia.

The implementation of such assimilation policy tended to limit the chamber or space of ethnic Chinese in Indonesia. The assimilation policy was implemented by banning all forms of activities on behalf of ethnicity such as abolishing Chinese ethnic schools, closing Chinese newspapers, violating the formation of Chinese socio-political organizations, and a policy of changing Chinese names into Indonesian names. In practice, the policy of assimilation also gave a significant impact on the existence of Chinese ethnic in Indonesia as well as the government itself. The impacts were diverse. On one hand, the policy of total assimilation has a negative impact, but on the other hand it also has a positive impact.

Basically, Soeharto had intimate relationship with some Chinese figures; however, it did not guarantee the discretion of the Chinese for politics. Suharto tended to have connections with Chinese in the economic field. It was fundamentally based on mutual relationships between the two parties which were practically referred to as "Cukong or broker". "The broker or 'well-to-do financier' provided capital, connections outside Indonesia, and trade flaws without threatening their partners in this respect because anti-Chinese sentiments in Indonesia mean that the broker could never build political power [11]. Nevertheless, political aspirations could still be channeled through leaders who were able to deal directly with President Soeharto. But still, President Soeharto did not allow the Chinese figures to become political figures. On this basis, Chinese politics during the New Order era was a type of broker politics [12]. In another perspective, the implementation of the assimilation policy by the New Order government was one of efforts to maintain their power. The concept of assimilation apart from political matters became a tool for maintaining power in the New Order government which could be seen from the limitation of Chinese ethnicity's chamber which was wrapped with assimilation policy; nevertheless, the New Order government gave economic opportunity. It became one of the indigenous distrusts of the Chinese who eventually made Chinese ethnicity the target of the riots that occurred at the end of the Soeharto government's collapse, during the riot of May 1998.

As it has previously been elaborated that after the implementation of the assimilation policy, all activities and spaces of ethnic Chinese in various areas of life are severely constrained, even absolutely isolated. In this regard, Indonesia is one of the countries implementing the policy of assimilation against ethnic Chinese in Southeast Asia other than Philippines, Thailand and Vietnam, yet the implementation of assimilation policy in Indonesia was the most radical in terms of policies that had been applied in solving ethnic Chinese problem.

\section{CONCLUSION}

The implementation of assimilation policies on one hand had had a significant impact on building a multicultural Indonesian society. Although the Chinese were in practically burdened by the regulations that tribulated them and the assimilation policies tended to lead to the destruction of their indigenous culture, they had unconsciously made a natural integrating process with those indigenous communities slowly and gradually. This had sooner or later led to a "sense of belonging" as an Indonesian citizen in the Chinese individuals who assimilated or integrated to the indigenous. The moral value which could be taken from this event was that the government and society had a share in creating harmony of 
life in order to create the integration and the unity of the nation. In addition, the differences of any ethnics or classes are not used as an excuse to cause conflict, but as a strong knot to jointly build the nation.

Respecting and appreciating the rights of each difference do not mean to abolish but to develop into a unity in diversity as revealed in the slogan of Indonesia. In practice, Indonesian government must draw a clear line between the foreign Chinese and the Indonesian citizens of Chinese descents, the latter to have the same positions, rights and duties as any other citizens. Any discriminatory treatment and exclusive association are also avoided

\section{REFERENCES}

[1] L. Suryadinata, Dilema Minoritas Tionghoa, Jakarta: Grafiti Pers, 1982.

[2] R. Wiriaatmadja, Pendidikan Sejarah Di Indonesia: Perspektif Lokal, Nasional, dan Global, Bandung: Historia Utama Press, 2002.

[3] M. G. Tan, Golongan Ethnis Tionghoa di Indonesia, Jakarta: Gramedia, 1981.

[4] B. G. Setiono, Tionghoa dalam Pusaran Politik, Jakarta: Trans Media, 2008.

[5] O. S. Kuncono, Gus Dur di Mata Orang Tionghoa Khonghucu, [Online]. Accessed from http://www.spocjournal.com/budaya/85-gusdur-di-mata-orang-tionghoa-khonghucu.html. 2012.

[6] L. Suryadinata, Etnis Tionghoa dan Pembangunan Bangsa, Jakarta: PT Pustaka LP3ES, 1999.

[7] L. Suryadinata, Dilema Minoritas Tionghoa, Jakarta: PT Temprint, 1986.

[8] C. A. Coppel, Tionghoa Indonesia dalam Krisis, Jakarta: Sinar Harapan, 1994.

[9] L. Suryadinata, Negara dan Etnis Tionghoa, Jakarta: Pustaka LP3ES, 2002.

[10] J. Suryomenggolo, Hukum sebagai Alat Kekuasaan: Politik Asimilasi Orde Baru, Jakarta: Galang Press, Elkasa, 2003.

[11] M. C. Ricklefs, Sejarah Indonesia Modern 1200 - 2008, Jakarta: Serambi Ilmu Semesta, 2008

[12] L. Suryadinata, Indonesia dalam Arus Sejarah Masa Orde Baru dan Reformasi, Jakarta: Ichtiar Van Hoeve, 2009. 